\title{
CHARACTERIZATION OF POULTRY PRODUCTION SYSTEMS IN THE RURAL SECTOR OF FAYOUM
}

\author{
M.A. El-Wardani, Y.A. Abdel-Aziz, Amal S. Omar, A.H. Abdelmaged \\ and O.M. Zatter \\ Animal Production Research Institute, Agricultural Research Centre, Ministry of \\ Agriculture, Dokki, Giza, Egypt
}

\section{SUMMARY}

One hundred and twenty-one rural poultry farmers in 12 villages in six districts of Fayoum governorate were studied through semi-structured interviews with questionnaires. The objectives of this study were to describe the existing village poultry production systems. Rural poultry farmers were identified as those who raise flocks either inside their houses or in attached enclosures, beside small farms who operated on semi-commercial basis under rural conditions. The chi-square was used to test all differences between systems except flock size data which allowed making ANOVA between systems, districts and villages between districts.

Systems identified were: 1) Backyard or family poultry production system; involves two sub-systems: traditional and landless systems, and 2) semi-commercial village poultry production system. Backyard system represented about $76 \%$ of the studied farms versus $24 \%$ for the semi-commercial system. Chickens represented the highest component of the flock composition (82\%) followed by pigeons and ducks $(8.2 \%$ and $8 \%)$, while geese, rabbits and turkeys represented minor percentages of $1 \%, 0.7 \%$ and $0.1 \%$, respectively. Local breeds are the dominating breeds in all systems. Average flock size was $70 \pm 6$ and $70 \pm 5$ birds in the traditional and landless systems, respectively, versus $1322 \pm 259$ birds in the semi-commercial system. Most of the farmers (58-67\%) in traditional and landless systems utilize poultry products for family consumption. In the semi-commercial system, only $10 \%$ of the products are used for home consumption and the rest (90\%) goes to the ordinary market channels. Poultry are usually housed in primitive coops (73-76\%) in traditional and landless systems. While in the semi-commercial system, poultry were generally raised in a room inside the house (66\%) or in a small pen attached to the house (34\%). Family labour is usually used. Disease control and unavailability of feed ingredients are major problems facing poultry production in the rural sector.

Keywords: Village poultry production systems, landless, backyard, semicommercial

\section{INTRODUCTION}

In Egypt, family poultry production is the dominant system and is a part of the rural life. It has been one of the support systems to subsistence farmers, providing supplementary food and income which are badly needed in rural areas. Most families

Issued by The Egyptian Society of Animal Production 
keep poultry in the backyard or on rooftop. The exact number of the rural poultry population, backyard family production, rooftop systems etc. is not known (Hosny, 2006). Chicken production in the rural sector is estimated at about 99.430 million broilers ( $17 \%$ of the total national production) and 1.2 billion eggs ( $29 \%$ of the total national production). There is no published data available on number of ducks, geese, turkeys, rabbits and pigeons (MALR, 2005). However, the rural sector is almost the sole source of ducks, geese and pigeons. A rural flock may hold different species of poultry, but chickens are mainly kept for egg and meat production, whereas turkeys, ducks, geese, rabbits and pigeons are mainly kept for meat production. Rural flock size can range from 10-20 birds up to a few hundreds (Hosny, 2006). Rural poultry sector depends mainly on local and improved local breeds.

Family poultry production in general and village chickens in particular represent a significant part of the rural and national economies (Gunaratne et al., 1993; Panda and Mohapatra, 1993; Guèye, 1998; Sonaiya et al., 1999 Guèye, 2000). According to a household expenditure survey for Egypt, poultry products account for nearly one third of the expenditure on animal protein products and account for 31 percent of the total food bill (AAFC, 2004). Sonaiya (1990) suggested the need to develop systems approaches to rural poultry development, and Lee et al. (1993) indicated that only by systems analysis, the production system could be better understood and interventions for improvement of production can be determined.

There is little available information about the management, constraints, and the productivity of rural poultry flocks and technological improvements that could be affordable to the low-input systems. The aim of this study -therefore- was to use systems approach to describe the existing village poultry production systems in rural areas and obtain reliable data on these systems in Fayoum governorate.

\section{MATERIALS AND METHODS}

A field survey was conducted on 121 randomly selected farmers in twelve villages in six districts of Fayoum governorate in middle Egypt. The number of poultry farmers surveyed in each of these villages is shown in table1. Data were collected as part of research study on development of market-oriented poultry production systems at the smallholders in rural areas, funded by the Egyptian National Academy of Scientific Research and Technology.The data were collected during the period from March to August, 2007.

A preliminary survey was conducted at the beginning to identify the village based poultry production and pilot-examine the survey formats. Poultry farmers in rural areas were identified as those operate in a village and raise flocks either inside or attached to their houses. They adopted simple management practices of poultry raised under rural conditions. One extension officer in each village was trained and assigned to collect data under supervision of the research team through weekly visits to the poultry farmers. The collected data included information on flock size, flock composition, flock structure, type of poultry, breeding purpose, housing systems, marketing, labour and constrains to improvement.

Enumeration data of the field survey were analyzed by the chi-square test of hypothesis and the Marascuillo procedure was used to test the significance of the proportions among systems (XLSTAT 1.01 computer program, 2009). The data collected on flock size were statistically analyzed by the least squares technique 
using the general linear model procedure of SAS program (SAS, 2005). The following linear model was used in the analysis:

$Y i j k=\mu+S_{i}+D_{j}+V_{k}\left(D_{j}\right)+e_{i j k}$, where

Yijk is the observed flock size,

$\mu$ is the general mean,

$\mathrm{S}_{\mathrm{i}}$ is the effect due to production system, $\mathrm{i}=1,2,3$ ( $1=$ Traditional, $2=$ =Landless and $3=$ Semi-commercial),

$D_{j}$ is the effect of the $j$ district $(j=1,2,3,3,4,5,6)$,

$V_{k}\left(D_{j}\right)$ is the effect of the $k$ village within district $j,(k=1,1,2,3,4,5,6,7,8,9,10,11,12)$, $\mathrm{e}_{\mathrm{ijk}}$ is a random effect associated with the individual observation and assumed to be independent, random and normally distributed.

Table1. Number of poultry farmers surveyed at different villages

\begin{tabular}{llc}
\hline Districts & Villages & Farmers \\
\hline El-fayoum & Zawia Elkerdasa & 9 \\
\multirow{2}{*}{ Snors } & Elazab & 10 \\
& Elkaapy & 10 \\
Tamia & Sanhor & 11 \\
& Kaffer Mahfouz & 11 \\
Epshway & Pander Tamia & 10 \\
& Abo-Denkash & 11 \\
Elseddeeq & Abo-kesaa & 10 \\
& Kaser Elgebaly & 9 \\
Atssa & Batn harred & 10 \\
& Elgaafra & 10 \\
\hline
\end{tabular}

\section{RESULTS AND DISCUSSION}

Based on criteria of capital investment degree (extensive, semi-intensive or intensive) and the economic purpose of the poultry owner (subsistence, semicommercial or commercial), the poultry production systems in rural areas can be classified -in general- into two main systems, 1) Back-yard or family poultry production system that involves two sub-systems; traditional and landless village poultry production systems and 2) Semi-commercial or small-farm poultry production system.

\section{A. Brief description of the systems}

1. Back-yard poultry production system: Back-yard or family poultry production is the prevailing system in nearly all the rural sector. The economic purpose of the poultry farmer is mainly to meet family needs (home consumption). The system involves little semi-subsistence-oriented production. In terms of capital investment it is considered as extensive system. Backyard poultry production system represented about $76 \%$ of the studied farms. Flock composition is heavily skewed towards chickens. This system involves two sub-systems; traditional and landless village poultry production systems. 
1.1. Traditional village poultry production system: A mixed system where livestock, including animals; poultry and crop production are integrated in the same farm. Poultry owners in this system have access to cultivated area for crop production with an average of 1.7 Fadden $\left(1\right.$ Fadden $\left.=4200 \mathrm{~m}^{2}\right)$. Poultry owners kept a limited number of different species of poultry, mainly chickens followed in numbers by ducks, geese, pigeons, turkeys and rabbits. This system represented about 41\% (50 farmers) of the total farmers surveyed. Around $49 \%$ of the families worked in the farm permanently and earned their living from agriculture. The other $51 \%$ of the households had permanent jobs out of the farm as employees and worked on their farms as secondary jobs.

1.2. Landless village poultry production system: This system is common in the vicinities of the relatively large towns in rural areas. Poultry farmers in this system do not have access to cultivated areas. Poultry farmers kept birds of varying ages and different species (mainly chickens, followed in numbers by ducks, geese, pigeons, turkeys and rabbits). Poultry owners represented about 35\% (42farmers) of the total farmers surveyed. The main profession for the largest portion of them is as employees or workers $(82 \%)$, the remaining $(18 \%)$ work as poultry farmers. Among the landless families in rural areas particularly women, poultry used to provide independent income for the family in most cases. The importance of poultry in income generation especially for the poor and landless is quite evident in the study area. In rural Egypt, poultry account for $72 \%$ of the total livestock income; chicken alone account for $61 \%$ of the livestock income (Croppenstedt, 2006).

2. Semi-commercial poultry production system: The semi-commercial poultry production system is rather market-orientated; therefore this system could be looked at as a transitional stage towards the commercial poultry production system. Poultry farmers who are involved in this system have to some extent management and marketing skills. It seems that more access to the know-how and capital are important factors for the development of this production system. The flock size is larger than the in other rural systems with four species being raised in this system (mainly chickens, followed by ducks, pigeons and rabbits). Poultry owners represented about $24 \%$ (29 farmers) of the total farmers surveyed. The majority of the poultry farmers are employees $(65 \%)$; the remaining $(35 \%)$ work as only poultry farmers.

Another point of view was presented by Bessei (1987) and Sonaiya (1990) who classified poultry production systems into: free-range system or traditional village system, backyard or family system, semi-intensive system and intensive system. According to Gueye (1998a), the free-range system or traditional village system and backyard or family system are the most commonly practiced in rural Africa. Gueye (1998a) added that more than $85 \%$ of the rural families in sub-Saharan Africa keep one or more species of poultry.

B. Main Features of the systems:

1. Family labour: All family members including women, children and men tend to be involved in rural poultry production. Women, assisted in some cases by children, play a key role in the family labour, especially in the traditional and landless poultry 
production systems. Daily managerial practices depend mainly on the women in $65 \%$ and $70 \%$ of the surveyed poultry farmers in traditional and landless systems, respectively. However, in the semi-commercial system farms depend mainly on men in $57 \%$ of the surveyed poultry farms as shown in table 2 .

Table 2. Family labour participation in poultry management in the different production systems (expressed as percentage of system totals)

\begin{tabular}{rcccc}
\hline \multirow{2}{*}{ Items } & \multicolumn{2}{c}{ Back-yard } & Semi-commercial & P-value \\
\cline { 2 - 3 } & Traditional & Landless & & \\
\hline Women only & $65^{\mathrm{a}}$ & $70^{\mathrm{a}}$ & $28^{\mathrm{b}}$ & 0.0001 \\
Men only & $22^{\mathrm{ab}}$ & $10^{\mathrm{a}}$ & $57^{\mathrm{b}}$ & 0.0006 \\
Family & $13^{\mathrm{a}}$ & $20^{\mathrm{a}}$ & $15^{\mathrm{a}}$ & 0.67 \\
\hline
\end{tabular}

Means with different letters within the same rows are significantly different.

In Egypt, poultry raising is a popular activity among rural women (Hosny, 2006). The same trend has been observed by Sonaiya, (2000) who stated that Nigeria family poultry is usually the responsibility of women. A major portion of backyard poultry production in the village is managed and implemented by women. In sub-Saharan Africa, more than $70 \%$ of the chicken owners are women, while traditionally pigeons are the responsibility of only children (Gueye, 1998b).

2. Types of poultry: Native breeds of poultry of different species are mainly kept followed in numbers by improved native breeds and exotic breeds as shown in table 3. The largest percentage of chicken of native breeds such as Fayoumi, Balady and Dandarawy (77\% and 61\%) are kept in traditional and landless systems, respectively. On the other hand the semi-commercial system included the largest percentage of improved native breeds such as Dokki4, Mandarah, Montazah, Matrouh, Bandara, ElSalam and Baheig (51\%) and exotic broiler strains (33\%).

Table 3. Poultry species* and breeds raised in the different production systems (expressed as percentage of the system totals)

\begin{tabular}{|c|c|c|c|c|c|}
\hline \multirow{2}{*}{\multicolumn{2}{|c|}{ Poultry species }} & \multicolumn{2}{|c|}{ Back-yard } & \multirow{2}{*}{$\begin{array}{c}\text { Semi- } \\
\text { commercial }\end{array}$} & \multirow[t]{2}{*}{ P-Value } \\
\hline & & Traditional & Landless & & \\
\hline \multirow[t]{3}{*}{ Chickens } & Native breeds & $77^{\mathrm{a}}$ & $61^{\mathrm{a}}$ & $16^{\mathrm{b}}$ & 0.0001 \\
\hline & $\begin{array}{l}\text { Improved Native } \\
\text { breeds }\end{array}$ & $23^{\mathrm{a}}$ & $39^{\mathrm{a}}$ & $51^{\mathrm{c}}$ & 0.0001 \\
\hline & $\begin{array}{l}\text { Exotic Broiler } \\
\text { strains }\end{array}$ & --- & --- & 33 & --- \\
\hline \multirow[t]{2}{*}{ Ducks } & Native breeds & $44^{\mathrm{a}}$ & $48^{\mathrm{a}}$ & --- & 0.47 \\
\hline & Exotic breeds & $56^{\mathrm{ab}}$ & $52^{\mathrm{a}}$ & $100^{\mathrm{b}}$ & 0.0001 \\
\hline \multirow[t]{2}{*}{ Rabbits } & Native breeds & $60^{\mathrm{a}}$ & $100^{\mathrm{b}}$ & -- & 0.0001 \\
\hline & Exotic breeds & $40^{\mathrm{a}}$ & --- & $100^{\mathrm{b}}$ & 0.0001 \\
\hline Geese & Native & 100 & 100 & 100 & --- \\
\hline Turkey & breeds & 100 & 100 & 100 & --- \\
\hline Pigeon & Native & 100 & 100 & 100 & --- \\
\hline
\end{tabular}

Means with different letters within the same columns are significantly different.

*Including geese, turkeys and pigeons were native breeds only. 
This emphasizes the importance of the native breeds for rural poultry production. This could be due to its tolerance to harsh weather conditions, lower feeding requirements and also to consumer preferences of the taste of eggs and meat of native breeds. No specific breed could be pinpointed in the rural poultry sector as it depends mainly on the local non-specified crosses between endogenous native breeds such as Fayoumi, Balady and Dandarawy or improved native breeds (Hoseny, 2006).

Duck farmers in traditional, landless and semi-commercial systems have the same attitude towards keeping exotic breeds in $56 \%$ and $52 \%$ and $100 \%$ of cases, respectively. Exotic duck breeds such as Muskovy and Pekin as shown in table 3. Similar trend has been observed in favour of the native rabbits breeds such as Balady White and Balady Red versus exotic rabbit breeds such as New-Zealand and Chinchilla. In the surveyed farms, only native breeds of geese, turkeys and pigeons were found. This reflects the preference of family poultry producers in rural sector to keep native breeds of these types of poultry.

3. Flock composition: Rural poultry farmers raised different species of birds, mainly chickens, followed in number by ducks, geese, pigeons and little numbers of turkeys and rabbits as shown in table 4. Chicken represented the highest population of the flock composition (82.0\%) followed by pigeons $(8.2 \%)$ and ducks $(8.0 \%)$, while geese, rabbits and turkeys represented minor percentages of about $1.0 \%, 0.7 \%$ and $0.1 \%$, respectively of the total numbers of poultry on the farms.

Table 4. Proportions of the farms raising different species of poultry under the studied production systems (expressed as percentage of system totals)

\begin{tabular}{lcccc}
\hline Poultry species & Traditional & Landless & Semi-commercial & P-Value \\
\hline Chicken & $58^{\mathrm{a}}$ & $68^{\mathrm{a}}$ & $85^{\mathrm{b}}$ & 0.0001 \\
Ducks & $18^{\mathrm{a}}$ & $18^{\mathrm{a}}$ & $6^{\mathrm{b}}$ & 0.0001 \\
Geese & $9^{\mathrm{a}}$ & $6^{\mathrm{b}}$ & --- & 0.0001 \\
Turkey & $1^{\mathrm{a}}$ & $0.5^{\mathrm{b}}$ & --- & 0.0001 \\
Pigeon & $12^{\mathrm{a}}$ & $7^{\mathrm{a}}$ & $8^{\mathrm{b}}$ & 0.0001 \\
Rabbit & $2^{\mathrm{a}}$ & $0.5^{\mathrm{a}}$ & $1^{\mathrm{b}}$ & 0.0001 \\
\hline \multicolumn{4}{l}{ Means with different letters within the same rows are significantly different. }
\end{tabular}

Chickens constituted $58 \%$ and $68 \%$ of the flock composition in traditional and landless poultry production systems, respectively versus $85 \%$ in the semi-commercial poultry production system. Family poultry flock composition is heavily skewed towards chickens in Africa as more than $85 \%$ of the rural families in sub-Saharan Africa keep one or more species of poultry (Gueye, 1998), and towards ducks in Asia and turkeys in Latin America (Brabnckaert and Gueye, 1999).

4. Flock size and structure: Flock size is more related to the objectives of the poultry farmer. The average flock size was 70 birds in both of backyard systems, and ranged between 13 and 199 birds and between 20 and 180 birds in the traditional and the landless poultry production systems, respectively. On the other hand, the average flock size of chickens in the semi-commercial system was 1322 birds, and ranged from 100 to 5000 birds (Table 5). This could be due to that poultry owners in the system are more market oriented and have access to market channels. The wide 
variation noted in the flock size in many rural areas, depends on household objectives (home consumption, income generating or both) and investment.

Table 5. Least squares means \pm standard errors of flock size under different production systems (birds)

\begin{tabular}{|c|c|c|c|}
\hline \multirow{2}{*}{ Items } & \multicolumn{2}{|c|}{ Back-yard } & \multirow{2}{*}{$\begin{array}{c}\text { Semi- } \\
\text { commercial }\end{array}$} \\
\hline & Traditional & Landless & \\
\hline Poultry flock size & $70 \pm 6^{\mathrm{b}}$ & $70 \pm 5^{b}$ & $1322 \pm 259^{\mathrm{a}}$ \\
\hline Chicken flock size & $41 \pm 5^{c}$ & $47 \pm 5^{b}$ & $1235 \pm 226^{\mathrm{a}}$ \\
\hline Duck flock size & $16 \pm 2^{b}$ & $14 \pm 1^{\mathrm{c}}$ & $575 \pm 312^{a}$ \\
\hline Geese flock size & $12 \pm 1^{\mathrm{a}}$ & $13 \pm 4^{b}$ & --- \\
\hline Turkey flock size & $9 \pm 4^{\mathrm{a}}$ & $7 \pm 4^{b}$ & --- \\
\hline Pigeon flock size & $19 \pm 4^{\mathrm{a}}$ & $13 \pm 3^{b}$ & --- \\
\hline Rabbit flock size & $9 \pm 3^{b}$ & $5 \pm 1^{c}$ & $125 \pm 3^{\mathrm{a}}$ \\
\hline
\end{tabular}

Means with different letters within the same columns are significantly different $(\mathrm{P}<0.05)$.

*Including chickens, ducks, geese, turkey, pigeons and rabbits.

Flock size was reported in some studies in Egypt to range from 10-20 birds up to a few hundreds depending on the objectives of the farmers (Hoseny, 2006). Flock size ranged from 4-130 birds in Philippines (Lambio, 2005) while in South East Asia, flock size ranged from 10 to 50 birds (Aini, 1999). Household flock sizes range from 3 to 97 birds in Africa, 10 to 31 in South America and from 50 to 2,000 in Asia (Brabnckaert and Gueye, 1999). The wide variations in rural flock size could be attributed to production system and local factors (Kuit, 1986).

With respect of flock structure, data were available only on chickens since other species were found in scattered small numbers. The largest flock size was that of the semi-commercial being 1235 birds with $100 \%$ young chicks and the smallest was that belonging to the traditional system ( 41 birds, of which $44 \%$ were young chicks). The flock size for the landless system was 47 birds, of which $61 \%$ were young chicks. The high percentage of chicks in the whole flock as compared to mature hens $(40 \%$, $32 \%)$, cocks $(4 \%, 3 \%)$ and pullets $(12 \%, 4 \%)$ for both of the traditional and landless systems, respectively could be due to the high mortality rate during incubation period. In general, the proportion of hens in the flock is an indication of egg and meat production of the farm (Mwalusanya, 1999, Abdou, 1992 and Wilson, 1987).

Table 6.Analysis of variance of flock size by system, district and village within district

\begin{tabular}{lcc}
\hline Source of variation & DF & MS \\
\hline System & 2 & $13.18^{* * *}$ \\
District & 5 & $0.18^{\mathrm{NS}}$ \\
Villages within district & 6 & $0.37^{* *}$ \\
Error & 107 & 0.08 \\
Corrected total & 120 & --- \\
\hline$* * * \mathrm{P}<0.0001, * * \mathrm{P}<0.01$ and $\mathrm{NS}=$ not significant. & &
\end{tabular}

Analysis of variance showed significant effects among systems $(\mathrm{P}<0.0001)$, and between villages within districts $(\mathrm{P}<0.01)$ as shown in table 6. However no 
significant differences were detected among districts which indicate the similarity among them as far as poultry production is concerned.

5. Source of chicken: For the same reason mentioned in the discussion of flock structure, source was studied only for chicken. Table 7 shows that traders are the main source of chickens (mainly day-old chicks) in the different production systems. Traders are the source of $41 \%-61 \%$ of the chickens in the surveyed farms depending on the system. This reflects the importance of poultry traders in rural areas. Local hatcheries are the only source of chickens in $5-14 \%$ of the cases. Governmental sites in Fayoum such as Al-Azzab integrated project and poultry research satiations are good source for chickens in the Semi-commercial and landless systems $(23 \%$ and $48 \%$, respectively).

Table 7. Source of chickens in the different production systems (expressed as percentage of the system totals)

\begin{tabular}{|c|c|c|c|c|}
\hline \multirow[b]{2}{*}{$\begin{array}{l}\text { Source } \\
\text { chickens }\end{array}$} & \multicolumn{3}{|c|}{ Production system } & \multirow[b]{2}{*}{ P-Value } \\
\hline & Traditional & Landless & $\begin{array}{c}\text { Semi- } \\
\text { commercial }\end{array}$ & \\
\hline Owner`s flock & $21^{\mathrm{a}}$ & $31^{\mathrm{a}}$ & --- & 0.57 \\
\hline Traders & $61^{\mathrm{c}}$ & $41^{\mathrm{a}}$ & $43^{\mathrm{a}}$ & .0001 \\
\hline Hatcheries & $14^{\mathrm{a}}$ & $5^{\mathrm{b}}$ & $9^{\mathrm{b}}$ & .0001 \\
\hline Governmental sites & $4^{\mathrm{bc}}$ & $23^{\mathrm{a}}$ & $48^{\mathrm{a}}$ & .0001 \\
\hline
\end{tabular}

6. Utilization of poultry and their products: Poultry owner's objective is usually more related to the production system. Table 8 shows that the two first systems (traditional and landless) are mainly directed towards home consumption (67\% and $58 \%$, respectively), and the surplus is sold in the local markets to increase family income. In the traditional system, $23 \%$ of the farmers sold most of their poultry and poultry products directly to the consumers in village and urban markets, where $10 \%$ of them sold their products to the traders. A similar trend was observed in the landless system as indicated in table 8 . The semi-commercial system is more marketoriented. Around $50 \%$ and $40 \%$ of the farmers in the semi-commercial system preferred to sell their products to regular markets and traders, respectively. The remaining $10 \%$ keep poultry and poultry product for home consumption.

Table 8. The utilization of poultry and their products in the different production systems (expressed as percentage of the system totals)

\begin{tabular}{|c|c|c|c|c|}
\hline \multicolumn{2}{|c|}{ Production Systems } & Home consumption & Market & Traders \\
\hline \multirow{2}{*}{ Back-yard } & Traditional & $67^{\mathrm{a}}$ & $23^{\mathrm{a}}$ & $10^{\mathrm{a}}$ \\
\hline & Landless & $58^{\mathrm{a}}$ & $25^{\mathrm{ab}}$ & $17^{\mathrm{a}}$ \\
\hline \multicolumn{2}{|c|}{ Semi-commercial } & $10^{\mathrm{b}}$ & $50^{\mathrm{b}}$ & $40^{\mathrm{b}}$ \\
\hline \multicolumn{2}{|l|}{ P-Value } & .0001 & .010 & .0001 \\
\hline
\end{tabular}

7. Housing: Poultry in the traditional and landless systems are usually housed in primitive coops that are built from locally available material in rural areas such as mud bricks and palm wood, reed or plant stalks. In most cases, these houses; are 
located either on the rooftops or attached to the house have no artificial light, and with small windows. The coop represents the largest percentage $(73 \%$ and $76 \%)$ for the traditional and landless systems, respectively, while in the semi-commercial system, poultry were generally kept in a suitable room inside the house $(66 \%)$ or in a small poultry house $(34 \%)$ as indicated in table 9.

Table 9. Types of housing under the different production systems (expressed as percentage of the system totals)

\begin{tabular}{|c|c|c|c|}
\hline Production Systems & Coop & $\begin{array}{c}\text { Room inside the } \\
\text { house }\end{array}$ & $\begin{array}{c}\text { Small poultry } \\
\text { house }\end{array}$ \\
\hline Traditional & $73^{\mathrm{a}}$ & $18^{\mathrm{a}}$ & $9^{a}$ \\
\hline Landless & $76^{\mathrm{a}}$ & $11^{\mathrm{a}}$ & $13^{\mathrm{a}}$ \\
\hline Semi-commercial & --- & $66^{\mathrm{b}}$ & $34^{\mathrm{b}}$ \\
\hline P-Value & 0.39 & .0001 & .0001 \\
\hline
\end{tabular}

8. Constraints to improvement: Feeding is a major problem in $20-25 \%$ of the surveyed farms followed by diseases and high mortality (20\%-24\%) in the different production systems; farms suffering from low production, lack of good incubation and housing facilities, and unavailability of appropriate poultry breeds represent together a considerable percentage of the surveyed farms in all systems (Table 10). Lack of equipment represented a minor problem $(1-2 \%)$ to landless and traditional systems, respectively. However, in the semi-commercial system the lack of equipment is a problem for $12 \%$ of the farms as the farmers purchase feeders and drinkers which are considered expensive.

Table 10. Type of problems facing rural poultry farmers in the different production systems (expressed as percentage of system totals)

\begin{tabular}{lcccc}
\hline \multirow{2}{*}{ Items } & \multicolumn{2}{c}{ Back-yard } & $\begin{array}{c}\text { Semi- } \\
\text { commercial }\end{array}$ & P-Value \\
\cline { 2 - 3 } & Traditional & Landless & \\
\hline Feeding & $22^{\mathrm{a}}$ & $25^{\mathrm{b}}$ & $20^{\mathrm{b}}$ & .0001 \\
Diseases and mortality & $24^{\mathrm{ab}}$ & $23^{\mathrm{a}}$ & $20^{\mathrm{a}}$ & .001 \\
Low production & $21^{\mathrm{a}}$ & $21^{\mathrm{b}}$ & $7^{\mathrm{c}}$ & .0001 \\
Incubation facilities & $12^{\mathrm{a}}$ & $13^{\mathrm{b}}$ & $12^{\mathrm{a}}$ & .001 \\
Breeds & $10^{\mathrm{a}}$ & $8^{\mathrm{a}}$ & $12^{\mathrm{a}}$ & .45 \\
Housing & $9^{\mathrm{a}}$ & $9^{\mathrm{b}}$ & $7^{\mathrm{a}}$ & .0001 \\
Equipment & $2^{\mathrm{a}}$ & $1^{\mathrm{a}}$ & $12^{\mathrm{b}}$ & .0001 \\
Marketing & --- & --- & 10 & --- \\
\hline
\end{tabular}

Means with different letters within the same columns are significantly different.

Traditional and landless systems have no problems in marketing and they are able to sell their products directly to the consumer or in the village market. Marketing problems were found in $10 \%$ in the semi-commercial system.

\section{ACKNOWLEDGEMENT}

This work is part of a study on the "development of market-oriented poultry production systems at the smallholders in rural areas". The authors would like to 
express their gratitude to the financial assistance provided to this study by the Egyptian National Academy of Scientific Research and Technology. Also, acknowledge the assistance received from Dr. M. A. Ibrahiem and Dr. U. El-Saied in the statistical analysis and Prof. S. Galal for reading of the manuscript and valuable advice.

\section{REFERENCES}

AAFC, Agriculture and Agri-Food Canada, 2004. Market Information Africa and the Middle East, July 2004.

Abdou, I., Bell, J.G., 1992. Dynamique de la volaille villageoise dans la region de Keita au Niger. In: Village poultry production in Africa, proceedings of an international workshop held in Rabat, Morocco, 7-11 May, 0 6-11.

Aini, I., 1999. Village chicken production and health: South-east Asian perspectives. FourthAsia-Pacific Poultry Health Conference. http:/www.avpa.cia.au/ confer/ideris. htm.

Bessei, W., 1987. Ttendencies of world poultry production . Proceeding of the third International dLG- Symposium on Poultry Production in Hot Climates, June 1922, Hameln, Germany .

Branckaert,R.D.S. and E.F. Gueye, 1999. FAO,s programme for support to family poultry production poultry as a tool in poverty eradication and gender equalityProceedings of a workshop, March 22-26, 1999, Tune Landboskole, Denmark.

Croppenstedt, A., 2006. Household Income Structure and Determinants in Rural Egypt, ESA Working Paper No. 06-02, FAO, Rome.

Guèye, E.H.F., 1998. Village egg and fowl meat production in Africa. World's Poultry Science Journal 54: 73-86.

Guèye, E.H.F., 2000. The role of family poultry in poverty alleviation food security and the promotion of gender equality in rural Africa. Outlook on Agriculture 29: 129-136.

Gueye,E.F., 1998. Poultry plays an important role in Africa Village Life. World Poultry, vol.14,NO,14-17.

Gunaratne, S.P., A.D.N. Chandrasiri, W.A.P. Mangalika Hemalatha, J.A. Roberts, 1993. Feed resource base for scavenging village chickens in Sri Lanka. Tropical Animal Health Production 25: 249-257.

Hosny,F.A., 2006. the structure and importance of the commercial and village based poultry system in Egypt. FAO publications. http://www.fao.org/docrep/008/af840e/af840e00.htm.

Kuit, H.G., A. Traore and R.T. Wilson, 1986. Livestock production in Central Mali: Ownership, management and productivity of poultry in traditional sector, Trop. Anim. Hlth Prod.18 222-231.

Lambio, A.L., 2005. "The Future Prospects for Smallholder Native Chicken Producers in the Philippines". Elpidio Quirino Professorial Chair Lecture. 24 June. ADSC Lecture Hall, UPLB-CA.

Lee, J.V.D., H.M.J. Udo and B.O. Brouwer, 1993. Design and validation of animal traction module for smallholder livestock systems simulation model. Agricultural Systems 43: 199- 227.

MALR, 2005. Ministry of Agriculture and Land Reclamation - Bulletin of Economic Affairs Sector, Egypt (In Arabic). 
Mwalusanya, N.A., 1999. Productivity and nutritional status of local chickens under village management conditions, INFPD Newsletter 2 18-20.

Panda, B., and S.C. Mohapatra, 1993. Poultry development strategies in India. World's Poultry Science Journal 49: 265-273.

S.A.S, 2005. SAS User's Guide: Statistics. SAS Inst., Inc., Cary, NC.

Sonaiya, E.B., 1990. The context and prospects for development of smallholder rural poultry production in Africa. In: CTA seminar proceedings, volume 1 . Smallholder Rural Poultry Production, Thessaloniki, Greece, pp. 35-52.

Sonaiya, E.B., R.D.S Branckaert and E.F. Guèye, 1999. Research and development option for family poultry. First INFPD/FAO Electronic Conference on Family Poultry.

Sonaiya, E.B., 2000. Backyard poultry production for socio- economic Advancement of the Nigeria Family: Requirement for Research and Development. Nigeria Poultry Science Journal 1: 88- 107.

Wilson, R.T., A. Traore, H.G. Kuit, and M. Slingerland, 1987. Chick mortality in scavenging village chickens in Sri Lanka, Trop. Anim. Hlth Prod. 19 229-236. XLSTAT 1.01 computer program, (2009). 


\section{توصيف نظم الإنتاج الداجني في القطاع الريفي في محافظة الفيوم}

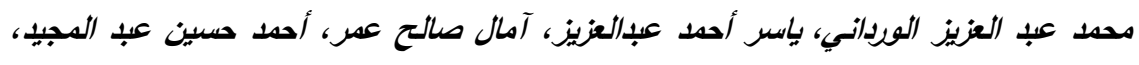

أسامه محمود محد زعتر

معهز بحوث الإتتاج الحيوانسي، مركز البحوث النزاعية، ونلرة الزراعة، الدقي، جيزة، مصر

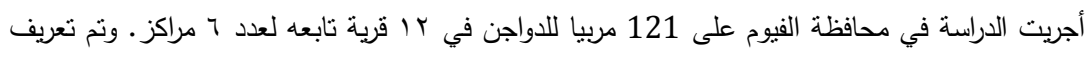

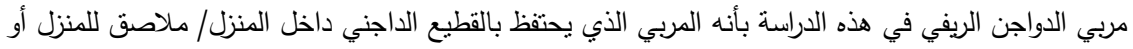

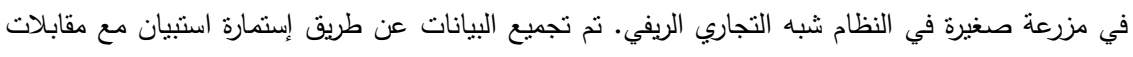

شخصيه. وكان الهدف من هذه الدراسة هو تحديد أنظمة إنتاج الدواجن السائدة في القطاع الريفي وتوصيفها.

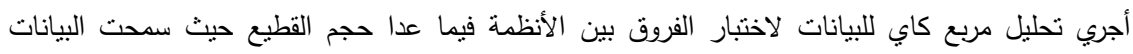

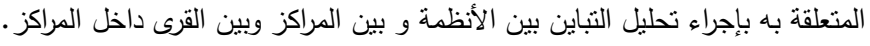

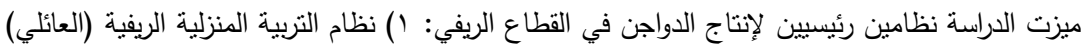

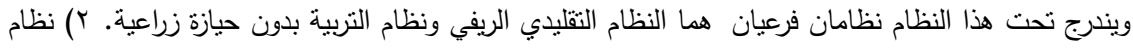

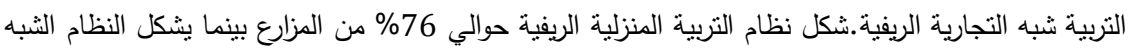

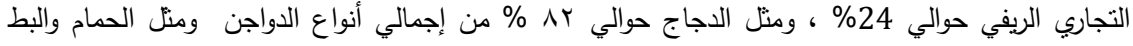

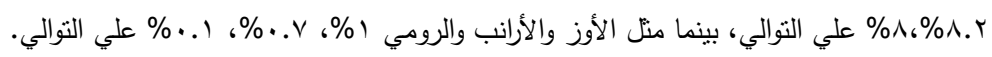

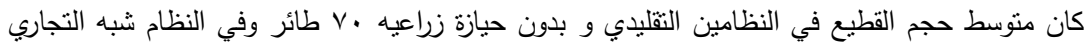

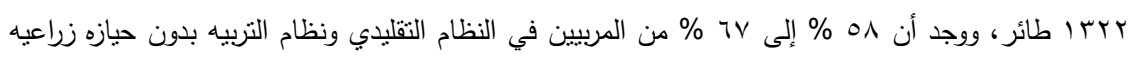

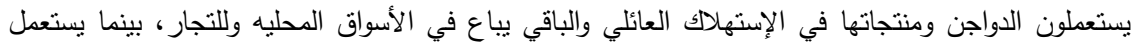

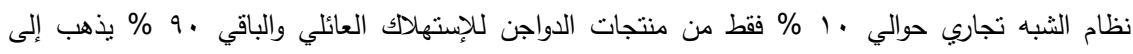

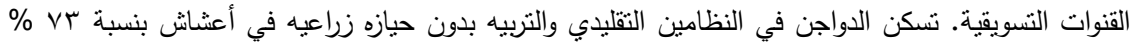

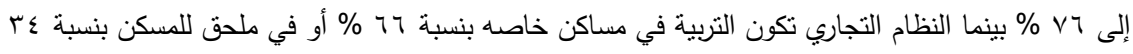

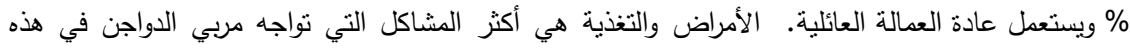
الأنظمة بالقطاع الريفي. 